v. $10, n .2$

Vitória-ES, Abr.-Jun. 2013

p. 120 - 137 ISSN 1808-2386 DOI: http://dx.doi.org/10.15728/bbr.2013.10.2.6

\title{
Marketing practices, between transactions and relationships, of companies in Brazil
}

\author{
Luciana Terra Targino ${ }^{\dagger}$ \\ $E A E S P-F G V$
}

André Torres Urdan ${ }^{\Omega}$

$E A E S P-F G V$

\author{
Marie Agnes Chauvel (in memoriam) ${ }^{¥}$ \\ Federal University of São João Del Rei
}

\begin{abstract}
Transactional marketing, for some time, reigned in theory and practice (SHETH; PARVATIYAR, 1995), highlighting the 4Ps (KOTLER, 2006). But some companies, especially in the services and industry sectors, began to have difficulty with the lack of personalization and interaction of such practice (HANKANSSON, 1982), (BRENTANI, 1991). In this context, emerged the Contemporary Marketing Practices Program (CMP). In it, Coviello, Brodie and Munro (1997) and Coviello, Milley and Macolin (2001), from conceptions of Grönroos (1996), pointed out five types of marketing as a function of the company/client interaction, four relational and one transactional. Results in several countries revealed the coexistence of relational and transactional marketing in many companies, but in different compositions. But ultimately, how does this phenomenon take place in Brazil? How does each marketing practice relate to business performance? This is a descriptive study, with data collected from executives, using the standard questionnaire of the CMP, plus a battery of questions about performance.
\end{abstract}

Keywords: Transactional marketing; relationship marketing; performance; marketing practices.

Received 07/05/2012; revised 10/25/2012; accepted 11/12/2012; published 06/28/2013

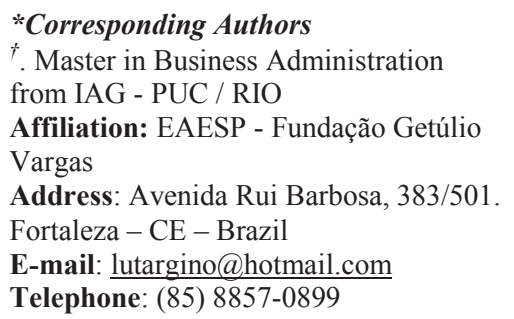

${ }^{\Omega}$ Doctor from Fundação Getúlio Vargas / SP Affiliation: Professor EAESP FGV/SP

Address: Av. 9 de Julho, 2029 - Bela Vista -

São Paulo - SP - Brazil

E-mail: andre.urdan@fgv.br

Telephone: (11) 3799-7700
${ }^{¥} \mathrm{PhD}$ in Administration

COPPEAD / UFRJ

Affiliation: Adjunct Professor of the Federal University of São João Del Rei - RJ - Brazil

Editor's Note: This article was accepted by Bruno Funchal 


\section{INTRODUCTION}

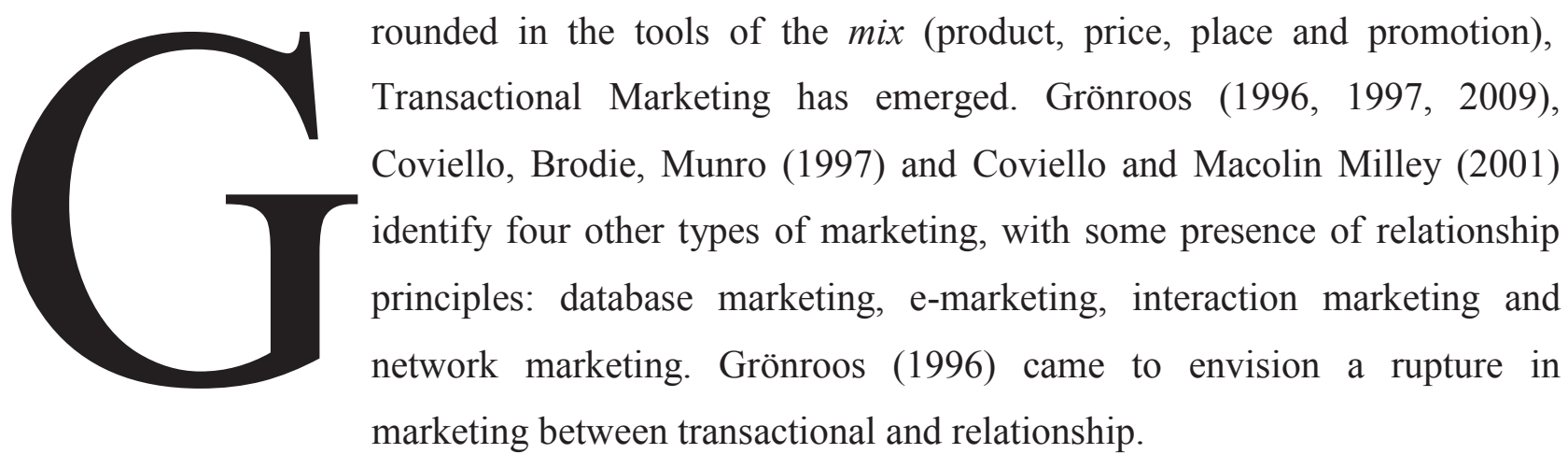

In 1996, began the program of Contemporary Marketing Practices (CMP, access in 14 sep. 2009), created by Rod Brodie and Nicole Coviello, School of Administration, University of Auckland, New Zealand. The purposes of the CMP are: i) to outline the marketing practices in different contexts in a comparative international forum; ii) to understand how companies relate to markets, visions between traditional marketing and more recent; iii) to identify antecedents and consequences of these practices ([http_1]). In essence, the CMP research revealed not the replacement of one type of marketing for another, but that relational and transactional marketing coexist. However, with this scheme, nothing is known of the Brazilian reality. Therefore, this article aims to draw a portrait of Brazil starting with the types of marketing in companies and the corresponding performances. For this, following, are four sections: theoretical framework, empirical method, results \& discussion, closing remarks.

\section{THEORETICAL FRAMEWORK}

The theoretical framework consists of two sections. The first covers the marketing types in CMP. The second section deals with the results of international research on the types and the gap that is rooted in the Brazilian reality.

\subsection{Types of Marketing}

In the framework of the CMP, the marketing types vary depending on the level of interaction of the company with customers from a distant and impersonal contact (focus on economic transactions) with passive consumers, until a close relationship, continuous, individualized, and focusing on an active role on the part of the consumers (COVIELLO, BRODIE; MUNRO, 1997). Relationship marketing seems to be a more general category, developing into more specific categories. Hong and Wang (2009), for example, distinguish relationship marketing with the context in mind, particularly among inter-organizational and company \& individuals, since each would have their own conceptualizations. Technological developments, expanding the range of application possibilities, would also recommend 
recognizing specific categories. Along this line, in order of increasing interactivity, a presentation on the five types of marketing of the CMP follows, from the transactional to the network, with the addition of some critical reflections.

\section{a. Transactional marketing}

In transactional marketing, the managerial intent is to attract customers (to satisfy them at a profit), and the decision making focus is on the product and/or brand (DAY, 2000). Business investment is aimed at internal marketing assets (product capabilities, pricing, distribution and promotion). Marketing professionals are specialized by function (such as sales manager and product manager). The horizon is the short term. This type focuses on economic transactions, whose parts are a company and buyers in the general market; communication takes place from the company to the market; contact is impersonal; the connection is intermittent or discrete, formal, with active sales personnel and passive buyers (COVIELLO et. al. 1997).

\section{b. Database Marketing}

The Database Marketing type is made up by sets of tools in information and technology. It is intended to capture information (especially economic) about customers and use it to increase profit, satisfy the customers and obtain greater loyalty (COVIELLO et. al., 1997). The company, by enrolling a customer in the database, is able to communicate with him in a personalized way (such as a message to a cell phone). But, in most cases, it adopts segmentation, wherein each group receives a homogenous treatment, in a partial personalization (LINDGREN, PALMER; VANHAMME, 2004).

In database marketing, communication is still from the company to the customer without his active participation or interaction. Contacts, although customized through technology, are still distant and formal. The supplier is active and buyers are only a little less passive than in transaction marketing (COVIELLO et al., 1997). There is little room for customer response to the actions of anyone who sells to them (LINDGREN et al., 2004). This type, among those in the relational perspective, is the closest to transaction marketing, as it is endowed with the lowest level of relationship.

CRM (Customer Relationship Management) computerized systems are a popular tool in database marketing. They offer information, forecasts and functions for managers to take proactive measures (XAVIER; DORNELAS, 2006). According to Chakravorti (2009), CRM 
improves knowledge about the company's clientele, which enriches the value of customers for the company and improves the management of them.

But there are snags. The model of Coviello et. al. (2001) does not address the customers' perception about the actions undertaken with Database Marketing. Bruhn, Tuzovic and Georgi (2009) argue that to convert the potential of the type into differentiation and competitive advantage is complicated. They found that calls from call centers and direct mail, common to the type, generate a negative perception of the customer about the company and do not stimulate loyalty; the customer does not interact nor continues the relationship. Many are the cases of huge and rich databases, but without much use. There are several reasons, such as the inability to process the analyses and difficulty to take advantage of them in practice. A challenge in database marketing is to mobilize the professionals towards proactivity in favor of positive surprise and satisfaction of the target (XAVIER; DORNELAS, 2006).

\section{c. E-marketing}

The e-marketing type focuses on the internet, and is by its nature very peculiar and innovative in dealing with the market (COVIELLO; DANAHER; JOHNSON, 2002). Its diffusion transforms the consumption of the people, gaining strength and sophistication through quick access to information on the Internet and facilitating contact with the companies as well as with other consumers (on forums, blogs, etc.). In e-marketing, dialogue between one seller and many identified buyers is installed. The company uses technology for interaction (dialogue), even in real time, "with" and "between" many individuals (who can form groups). Linking is formal yet personalized. It invests in internal operational assets (information technology, websites, logistics) and the integration of functional systems (purchase order, monitoring processing, feedback about the experience, etc.). There are marketing experts, technology experts and senior managers (COVIELLO et al., 2001).

Such development intensifies the pressure on marketers to set aside mass communication in favor of individualized communication (CONSTANTINIDES, 2006). Given the marked effects of the internet, Hong and Wang (2009) have postulated to review the concepts of relationship marketing. They ask for further studies to understand how consumers and businesses are coping with the set of technological tools.

In another aspect, Day and Hubbard (2003) recognize the advantages of the internet (such as to reduce the cost of searching for products), but point out that it is a platform, not a 
strategy to support and complement the other ends and means of marketing . It's what happens with a database, for example, enhanced with the activation of a function to send emails (DAY; HUBBARD, 2003).

For e-marketing, Kalyanam and McIntyre (2002) indicate a version of the 4Ps, the $e$ marketing mix, designed for relationships, exchanges and interactions in the digital world wide web. This would help to overcome the limitations of the traditional composite (as in mass communication and supply without personalization). The e-marketing mix would make it feasible to adjust what is taken and delivered to desire and to individualized behavior by means of resources such as the site for product configuration, in a wide range of possible combinations, by the potential buyer himself, the options of the attributes (KALYANAM; MCINTYRE, 2002).

\section{d. Interaction Marketing}

Interaction marketing is the type of marketing that best matches what Berry (1983) and Grönroos $(1996,1997)$ qualify as relationship marketing in services. It is based on the direct and close connection of the company with its stakeholders in order to facilitate transactions (LINDGREN et al., 2004). Marketing activities aim to develop cooperation with the customer. The process involves individuals who initiate and handle personal and complex interactions (LINDGREN et al., 2004), and have the requirements of confidence and commitment (GRÖNROOS, 2009). The links between the company and other parties are interpersonal (one on one) and continuous, with a focus on long-term and specific clients, individuals, companies or other organizations (COVIELLO et al., 2001). In interaction marketing, activities are conducted by many employees of various levels and functions, whether directly marketing professionals or not; these, Grönroos (2009) calls partial marketing professionals.

\section{e. Network Marketing}

Network marketing, configured by multiple business relationships, is the largest type of interaction. Interrelations are developed among firms to coordinate activities between multiple parties (BALESTRIN; VARGAS, 2004). In a broader marketing system (customers, suppliers, government, media and other stakeholders) mutual benefits are generated through exchange of information and other resources (COVIELLO et al., 2002). This type of marketing, according to Hankansson (1982), enables access to various resources that generate value for customers, without the company having to articulate its own suppliers and 
intermediaries. The company selects a small number of other organizations, and between them a network is formed (LINDGREN et al., 2004). On the network, various forms of interaction are established, including the flow of goods and services to the financial and social exchanges (ANTUNES; RITA, 2008). Since the management of network marketing is strategic, the one who usually takes care of that is a company's chief executive (HANKANSSON, 1995).

The network relations are not isolated, recalls Hankansson (1995); therefore they lie in the collective context of various relationships between companies, customers, suppliers, these suppliers with other suppliers and so on. With no other connections, the nature of a relationship becomes misunderstood. The performance of these firms depends on the competence to jointly develop the relationships and resources. In this, the more successful the other party is, the better for the company; the more this party helps a partner, the more all tend to gain.

\subsection{Research Abroad and the Gap in Brazil}

In the orbit of CMP, empirical research has been undertaken in some countries. Coviello, Brodie e Munro (1997) covered the nations of Europe and the United States, yet without including e-marketing. Those who used transactional marketing: i) also adopted the database and almost did not apply the interaction; ii) offered goods and were large and old. Those that applied primarily database marketing were large, ancient and made sophisticated use of technology. The practice of interaction marketing in general also ran network marketing; dealt with consumer goods and had low staff turnover. Finally, the strong companies in network marketing were characterized by foreign ownership and the more sophisticated use of technology.

In Argentina, Pels and Brodie (2004) detected five business segments, excluding emarketing: a) Traditional I, having Interaction Marketing as the main type, but also applying the Transaction and Database; b) Traditional II, with plenty of Transaction Marketing and less use of Database; c) Progressive I, trailing all four types of marketing considered and consisting of foreign companies; d) Progressive II, evidenced by Transaction Marketing; e) Progressive III, which drives all four types of marketing with smaller Argentine companies.

In Russia, Wagner (2006) mapped three segments. The first uses interactive marketing. The second stands out by having transactional marketing, with organizations little oriented to the market. The third segment adopts all five types of marketing. In general, transactional 
marketing was very much present in that country, with relationship practices only complementing it.

In short, the results accumulated by the CMP Program point to little use of one pure type of marketing. Many companies follow, instead, a "mixed" marketing with more than one type applied simultaneously. The presence of transactional marketing is strong, which prevents its rupture by the relationship (COVIELLO, BRODIE, MUNRO, 1997; COVIELLO, BRODIE, 1998; COVIELLO et al., 2002, GRÖNROOS 1997, 2009).

Despite the many studies about the multiple aspects of relationship marketing, in Brazil a survey in the wake of CMP and its marketing types was missing. Ultimately, what is the national scene in terms of such practices? In the annals of ENANPAD for the last ten years, there is no article with this vision, a sign of a basic scientific gap. It is important to identify the types of marketing forces in Brazilian companies, as well as the performances obtained, which requires an empirical investigation.

\section{EMPIRICAL METHODS AND PROCEDURES}

The main objective of this article is to map marketing practices in companies operating in Brazil and assess the resulting performance. It respected the method of CMP, to give rise to comparisons between countries. Of special interest would be to contrast the characteristics of the BRIC (Brazil, Russia, India and China).

A descriptive scheme was followed (IACOBUCCI, CHURCHILL, 2009). A questionnaire was developed from the last version of the standard CMP questionnaire (PELS; BRODIE, 2004), which comprises the five types of marketing. The original English text was passed into Portuguese with reverse translation. For each type, there is a non-comparative Likert scale from 1 to 5 . The respondent reports his degree of agreement or disagreement with each statement (MALHOTRA, 2006). Added are a battery of Likert scales, from one to five points, for the subjective assessment of performance marketing and finance. The pretest of the instrument revealed some difficulties in understanding translated excerpts and the formulation of the questions; modifications were made.

Due to the considerable length of the standard questionnaire (PELS; BRODIE, 2004), here augmented with performance measurement, only four additional variables were entered to characterize the company: what it offers to the market; what market it serves; the role of technology (IT) in its marketing; the technological level of the company. The performance, concerning the last three years, covered: i) aspects of marketing, customer service, sales to 
existing customers, sales to new customers, market share and competitive advantage, ii) aspects of financial profit margin, return on assets, return on investment.

\subsection{Sample}

The extraction of the sample was not probabilistic. D \& B of Brazil Ltda., specializing in databases, was asked for a list of companies in Brazil containing the name, address and email of the responsible marketing professional (manager and/or chief executive). In the survey, to ensure understanding of the subject, a respondent was asked to occupy at least the manager position and to possess good insight into other areas of the company. From the initial database, with 3,000 firms, 1,000 were randomly selected, to which was sent by mail, a nominal letter addressed to the executive named in the database, explaining the purpose of the research and inviting him to participate. The letter gave the site to access the survey and a password. The purpose of this printed letter was to provide credibility and prevent spam blockages that could impede an e-mail invitation from arriving to the recipient. Fifteeen days after posting, an email was sent to the persons in the initial sample, reinforcing the invitation. 128 valid questionnaires were obtained, a good response rate $(13 \%)$, since they were collected via the internet. However, this collection makes it difficult to know if the seniority of the respondent was always respected.

\subsection{Techniques of Data Analysis}

Cluster Analysis was applied, in order to classify objects or cases into relatively homogeneous groups, according to their characteristics here in question (HAIR et al., 2009). Hierarchical grouping was chosen and, for the unification of the groups, the measure of "Euclidean distance" of similarity between the companies regarding the type of marketing (HAIR et al., 2009). Cluster analysis requires scale reliability, consistently reflecting the construct. Then, the Cronbach alpha coefficient was calculated, which hit 0.94, excellent, close to the maximum (1.00). To set the number of clusters, besides the theoretical basis, the sensitivity of the researcher matters.

To probe differences between segments in their averages for each type of marketing, the Analysis of Variance (ANOVA) was used. This technique simultaneously tests more than two independent variables, thus reducing the probability of error which one would have with various t-tests when comparing the averages two by two. Complementing the ANOVA, the Post Hoc test evaluates the difference of averages two by two (VIEIRA, 1969). 


\section{RESULTS AND DISCUSSION}

In the sample, $60 \%$ of the companies are engaged in other companies/organizations, which was not expected. Part of this high proportion is due to the fact that Brazil is a country with a varied economy, filled with suppliers of raw materials, components and products in the B-to-B sphere, both internally and overseas (ALMEIDA, 2006). Yet 27.6\% of firms serve both the end consumers as well as the companies/organizations. The remainder $(12.4 \%)$ deals only with end consumers. In terms of outputs, of the sample: a) $40 \%$ offer goods; b) $41.4 \%$, both goods and services; c) $18.6 \%$, only services.

The members of the sample are probably medium or large because a filter required at least a marketing manager in the framework, which is not common in smaller companies. Incidentally, in the Central Register of Enterprises (CEMPRE) of 5.7 million firms in Brazil in 2006: a) $92.2 \%$ was micro; b) only $0.2 \%$ was large (IBGE, 2008). Therefore our sample is far from representing the entire population with regard to size.

\subsection{Clustering Analysis}

Three arrangements of clusters were examined: with three, five and six segments. The first followed the results of Coviello et al. (1997). The test with six segments accompanied the findings of Pels and Brodie (2004). The final amount was due to the fact that there are five types of marketing, and it was wanted to determine whether, in the Brazilian sample, the groups used each of the practices alone or not. The breakdown of the sample elements improved with five segments, baptized, according to the salient features in each of them, as Refractory, Transactional/Interactive, Advanced, Moderate and Unique. Table 1 shows the size and segment averages of using each type of marketing. The averages of the use of each type of marketing in the five segments are not all equal, as ANOVAs results summarized in Table 1 indicated, which shows there is enough heterogeneity of the segments with respect to types of adoption. 
Table 1 - Use of the types of marketing segment in solving the clustering analysis with five groups and results of ANOVAs for differences in each type, between the averages of the segments.

\begin{tabular}{|c|c|c|c|c|c|c|c|}
\hline \multirow[b]{2}{*}{$\begin{array}{l}\text { Business } \\
\text { segment }\end{array}$} & \multicolumn{2}{|c|}{ Companies } & \multicolumn{5}{|c|}{ Averages of the type used in marketing ( 1 through 5) } \\
\hline & $\mathrm{n}$ & $\begin{array}{c}\mathrm{n} \\
(\%)\end{array}$ & $\begin{array}{c}\text { Transactional } \\
\text { Marketing }\end{array}$ & $\begin{array}{l}\text { Database } \\
\text { Marketing }\end{array}$ & $\begin{array}{c}\text { E- } \\
\text { marketing }\end{array}$ & $\begin{array}{l}\text { Interaction } \\
\text { Marketing }\end{array}$ & $\begin{array}{r}\text { Network } \\
\text { Marketing }\end{array}$ \\
\hline Refractory & 3 & 2 & 2.3 & 1.6 & 1.7 & 2.1 & 1.6 \\
\hline Transactional/ & & & & & & & \\
\hline Interactive & 105 & 82 & 3.5 & 3.2 & 2.9 & 3.6 & 3.2 \\
\hline Advanced & 17 & 13 & 4.3 & 4.3 & 4.6 & 4.7 & 4.7 \\
\hline Moderate & 2 & 2 & 3.8 & 3.4 & 3.4 & 4.3 & 3.9 \\
\hline Unique & 1 & 1 & 3.8 & 2.7 & 2.9 & 3.9 & 4.2 \\
\hline Total & 128 & 100 & & & & & \\
\hline Anova, F & & & 16.5 & 26.7 & 20.2 & 15.7 & 18.1 \\
\hline Anova, Signif. & & & 0,00 & 0,00 & 0.00 & 0.00 & 0.00 \\
\hline
\end{tabular}

The Refractory segment, with a mere $2 \%$ of the sample, does not expressively apply any type of marketing, since most of them did not go beyond averages of 2.3 ( 5 is the maximum of the scales). However, in this segment, the Post Hoc test did not detect significant differences in the application of the types of marketing.

The Transactional/Interactive segment is proportionally huge, composed of $82 \%$ of the sample. All kinds are practiced moderately, although there is a little more strength in transactional marketing and interaction marketing. The e-marketing is the least used (average 
2.9). Moreover, it is only in this segment that the average types are significantly different (revealed by Post Hoc testing).

In the Advanced segment, comprising $13 \%$ of the sample, sharp use of all types of marketing intervenes, with averages between 4.3 and 4.7. Although these averages are not significantly different, lower standard deviations (from 0.3 to 0.4 ) indicate that the segment is fairly homogeneous in their profile of practices.

The Moderate segment, comprising 2\% of the sample, adopts reasonably all types of marketing. The average marketing interaction is higher (4.3). The Post Hoc, however, did not detect significant differences between averages and therefore it cannot be inferred that interaction marketing is typical there.

The Unique segment has only a single company, being somewhat more pronounced transactional, interaction and networking types, with no significant difference between their averages and those of other types. In analyzes of clusters with three and six segments, one segment equal, with a single element, emerged. This company could be the same in all three arrangements, having unique characteristics compared to the sample. Table 2 summarizes the marketing practices by segment, along with some general business characteristics.

Two of the three companies in the Refractory segment catered to end consumers and one to companies/organizations. All companies in this segment offered goods.

In the Transactional/Interactive segment, $60 \%$ of the companies attended other companies/organizations and $28 \%$ both end consumers as well as other companies/ organizations; $44 \%$ of the segment offered goods; and $40 \%$, goods and services. These percentages are similar to those of the entire sample.

In the Advanced segment, $77 \%$ of the companies attended companies/organizations, $53 \%$ of both goods as well as services. The remaining were divided equally among only goods and only services. The fact that most companies of the segment add services to the goods may explain the high levels in the types of Marketing used. The advantages of relationship marketing practices to create value for customers may be realized, as proposed by Grönroos (2009).

All companies in the Moderate segment serve companies/organizations and offer both goods and services. The only company in the Unique segment serves companies/ organizations with goods. 
Table 2 - Overview of Marketing Practices of Brazilian companies in the sample

\begin{tabular}{|c|c|c|c|c|}
\hline $\begin{array}{c}\text { Overview of } \\
\text { Marketing } \\
\text { Practices of } \\
\text { Brazilian } \\
\text { Companies in } \\
\text { the } \\
\text { SampleStrategic } \\
\text { Segments } \\
\end{array}$ & $\begin{array}{c}\text { Number } \\
\text { of } \\
\text { Companies }\end{array}$ & $\begin{array}{c}\text { Number } \\
\text { of } \\
\text { Companies } \\
(\%)\end{array}$ & Name of Segment & $\begin{array}{c}\text { Main features of the segments } \\
\text { generated }\end{array}$ \\
\hline 1 & 3 & $2.3 \%$ & Conservative & $\begin{array}{l}\text { None of the types of marketing is } \\
\text { practiced widely. Offers only products } \\
\text { to market. Caters mainly to end } \\
\text { consumers. Technology is used to } \\
\text { support marketing activities. The } \\
\text { technological level of the companies is } \\
\text { too low (2.3). }\end{array}$ \\
\hline 2 & 105 & $82.0 \%$ & $\begin{array}{c}\text { Transactional / } \\
\text { Relational } \\
\text { Interactive }\end{array}$ & $\begin{array}{l}\text { Practice transactional marketing and } \\
\text { relational/interactive. Offers both } \\
\text { products only and products / services to } \\
\text { market. Caters primarily to companies / } \\
\text { organizations. IT serves to support } \\
\text { marketing. The technological level of } \\
\text { the companies is medium (3.5) }\end{array}$ \\
\hline 3 & 17 & $13.3 \%$ & Advanced & $\begin{array}{l}\text { Practices the five types of marketing } \\
\text { significantly, 50\% of companies offer } \\
\text { products / services to market, and only } \\
25 \% \text { offer products and services only. } \\
\text { Caters primarily to companies / } \\
\text { organizations. IT serves to support and } \\
\text { expand / develop marketing activities. } \\
\text { The technological level of the } \\
\text { companies is high (4.1) }\end{array}$ \\
\hline 4 & 2 & $1.6 \%$ & Moderate & $\begin{array}{l}\text { Makes use of the practices of } \\
\text { relationship marketing "moderately". } \\
\text { Offer products / services to market. } \\
\text { Serves companies / organizations. IT is } \\
\text { used to support marketing activities. } \\
\text { The technological level of the } \\
\text { companies is "moderate" (3.5). }\end{array}$ \\
\hline 5 & 1 & $0.8 \%$ & Unique & $\begin{array}{l}\text { Cannot conclude what type of } \\
\text { marketing is practiced. Offers product } \\
\text { to market. Serves companies / } \\
\text { organizations. IT gives marketing } \\
\text { support. The technological level of the } \\
\text { company is "very low" (2.0). }\end{array}$ \\
\hline
\end{tabular}

As for the technological level of the company, it is low in the Refractory segment (average 2.3), and information technology serves only to support marketing activities. In the largest segment of the sample, the Transactional/Relational Interactive, the technological level is "moderate," and $81 \%$ of the role of information technology goes to support marketing activities, while $14 \%$ are to expand and develop marketing efforts. The Advanced segment has 
the highest technological level (average 4.1); in it, information technology especially supports marketing activities (71\%), but also expands/develops marketing activities (29\% frequency). This segment, perhaps by having advanced features in marketing, seems ahead of the others in the use of technological possibilities. The Moderate segment holds a technological level "moderate" (average 3.5), with information technology supporting only marketing activities. One company in the segment presents the technological level "low" (2.0) and IT supports its marketing efforts.

Only the Transactional/Interactive segment held, in ANOVA, averages significantly different in variables on corporate performance in the last three years. In this segment, the Games-Howell test indicates that the best performance was in the marketing variable "Sales to current customers" (average 4.0), followed by the variable "Market Share" (average 3.8). Scores that were significantly higher than those of other marketing and financial variables. The Games-Howell also signaled that companies in the segment did not obtain favorable financial performance in the period. The averages of 3.4 in the variables "profit margin", "Return on investment" and "Return on assets" are significantly lower than the best performing variables already mentioned. A similar result was the marketing variables "Sales to new customers" and "Competitive Advantage", with performance similar to those of financial variables, something not so satisfactory. In these respects, for the other segments it was not possible to reach conclusive results.

\section{FINAL CONSIDERATIONS}

Presented here is an overview of the marketing practices of a sample of Brazilian companies and an evaluation of the financial and market results obtained, in the line of the CMP Program, in the non-probabilistic sample of managers or occupants of the highest positions of 128 companies.

In the sample, companies practice, significantly, both transactional marketing as well as interaction marketing. This corroborates the theoretical conception that there was not a split between those practices, but rather, they coexist in companies (COVIELLO et al., 1997; PELS et al., 2000; COVIELLO et al., 2002; ZINELDIN; PHILIPSON, 2007).

Practitioners of transactional marketing and interaction marketing, in the transactional/relational interactive segment, accounted for most companies (82\%). They provide goods and services to the market or just goods and mostly attend other organizations. This contradicts the proposition that companies with transactional marketing offer goods and those practicing relationship marketing offer services (COVIELLO et al., 2002). However, 
Brazilian companies in the sample seem to be waking up to the advantages of relationship marketing, providing value to goods and services.

In a crucial surprise, the practice of transactional/relational interactive marketing did not bring (in the evaluation of the executives) very good marketing and financial performance for the companies. The exception was with "Sales to current customers," a possible result of hybrid action between transaction and interaction marketing. Customers can be satisfied with the goods or services, and companies should know how to keep them with an interactive approach. Also considered was the value for the customer by linking the service to the good, according to Grönroos (2009). Another possible interpretation is that these companies are not technologically prepared to act more aggressively in the market, given the moderate level of technology in the transactional/relational interactive segment.

Another segment (13\% of the sample) draws attention: the "Advanced", whose companies employ all the types of marketing considered. Its profile is similar to that observed in Progressive I and III segments in the search by Pels and Brodie (2004), conducted in Argentina. A search of Wagner (2005) also detected a segment of users of all types of marketing.

In this "Advanced" segment there is also a contrast to the theory, already questioned by Coviello et al. (2002), with regard to the provision of services by companies practicing relationship marketing. Here in the sample, most companies in this segment offer goods and services. They have, in addition, the highest technological level among different segments. Information technology supports marketing activities, but also serves to expand/develop marketing activities, as noted by Hong and Wang (2009), when they elucidated the importance of technology in changing marketing relationships.

There is also a small group of companies in Brazil, the "Refractory" segment, which does not use any of the types of marketing in a considerable way ( $2 \%$ of the sample). Companies which are in this group increasingly realize the importance of marketing.

A fourth segment of companies with an equally small portion of the whole $(2 \%$ of the sample), applies all types of marketing, but moderately; moderation that occurs even in the technological level. They proffer goods and services and cater to other businesses and organizations, as do most Brazilian companies.

The Advanced segment is the only one to excel in technology. Still, only $29.4 \%$ of its companies use technology to expand and develop their marketing activities. Most companies 
in the sample use technology only for supporting marketing activities, and not more broadly, contributing to the definition of their business. Almeida (2006) proceeds to affirm with a very convincing definition of Brazil:

[...] A country such as Brazil is contradictory: an industrial giant and at the same time, a technological dwarf, a major economic power by its gross production [...], a major global supplier of many raw materials essential for the operation, at full throttle, of the "furnace of capitalism."

Altogether, the vast majority of the sample companies apply the same approach to relationship marketing: transactional/relational interactive. This can make it difficult to differentiate between them and cause lower marketing and financial performance.

Given this overview of the marketing practices of companies in Brazil, there is much to explore about their adopters, antecedents and consequences. More research is needed on this issue; further investigation of the segments described and identification of inhibiting factors of relational marketing practices, those who urge the adoption of hybrid marketing, understanding better the role played by technology as well as the impact of marketing practices on business performance. It would also be interesting to study the theme focusing on companies that concentrated on the end consumer. It is suggested, moreover, future research comparing the segments found in this study, to other variables such as nationality of capital controls, scale, and investment in training people. Finally, a qualitative study of the marketing managers of companies from various segments would cause a better understanding of the relationships among the variables considered here.

\section{LIMITATIONS OF THE STUDY}

In addition to the limitations already pointed out, despite the international importance of the scheme of Coviello et al. $(1997,2001)$ on types of marketing, there may be other relevant proposals that were not covered here, but explained in the introduction. Another important limitation of this research stems from the lack of significant differences between the averages of the performance of the Refractory, Advanced, Moderate and Unique segments. This prevented the identification of marketing practices that bring the best financial and marketing results. Even on these variables, it cannot be affirmed that good or bad company performance arises only from marketing practices. There are many other factors that may affect it and that were not considered or controlled in the research of this article. 


\section{REFERENCES}

ALMEIDA, P. R. O estudo entre as relações internacionais do Brasil: um diálogo entre a diplomacia e a academia. Brasília: LGE, 2006.

ANTUNES, J.; RITA, P. O marketing relacional como novo paradigma: uma análise conceptual. Revista Portuguesa e Brasileira de Gestão, Lisboa, v. 7, n. 8, p. 36-46, abr. 2008.

BALESTRIN, A.; VARGAS, L. A dimensão estratégica das redes horizontais de PMEs: teorizações e evidências. Revista de Administração Contemporânea, Rio de Janeiro, Edição Especial, p. 203-227, 2004.

BERRY L. L. Relationship marketing In: L. L. BERRY; G. L. SHOSTACK; G. D. Emerging perspectives on services marketing, UPAH, Chicago: American Marketing Association, 1983. p. 25-38.

BRENTANI, U. Success factors in developing new business services. European Journal of Marketing, v. 24, n. 2, p. 33-59, 1991.

BRUHN, M.; GEORGI, D.; TUZOVIC, S. The link between marketing instruments and customer perceptions. Journal of Relationship Marketing, v.8, n. 1, p. 50-67, 2009.

CHAKRAVORTI, S. Extending customer relationship management to value chain partners for competitive advantage. Journal of Relationship Marketing, v. 8, n. 1, p. 299-312, 2009.

CMP - Contemporary Marketing Practices Programme. Disponível em:

$<$ http://www.business.auckland.ac.nz/uoa/home/about/our-research/bs-researchgroups/contemporary-marketing-practices-programme>. Acesso em: 14 set. 2009.

CONTANTINIDES, E. The marketing mix revisited: towards the 21 st century marketing. Journal of Marketing Management, v. 22, n. 3, p. 407-438, 2006.

COVIELLO, N. E. et al. How do firms relate to their markets: an empirical examination of contemporary marketing practices. Journal of Marketing, v. 66, n. 3, p. 33-46, jul 2002.

COVIELLO, N. E.; BRODIE, R. J.; MUNRO, H. J. Understanding contemporary marketing: development of a classification scheme. Journal of Marketing Management, Helensburgh, v. 13, n. 1, p. 501-522, jan 1997.

COVIELLO, N. E.; MILLEY, R; MARCOLIN B. Understanding IT: enabled interactivity in contemporary marketing. Journal of Interactive Marketing, Hoboken, v. 15, n. 4, p. 18-33, Autumn, 2001.

DAY, G. F.; HUBBARD, K. J. Customer relationships go to digital. Business Strategy Review, Londres, v. 14, n. 1, p. 17-26, Spring 2003.

DAY, G. S. Managing market relationships. Academy of Marketing Science Journal, Greenvale, v. 28, n. 1, p. 24-30, Winter 2000.

GRÖNROOS, C. Marketing: gerenciamento e serviços. Rio de Janeiro: Elsevier, 2009. 
GRÖNROOS, C. The rise and fall of modern marketing: and its rebirth. In: SHAW, S.; HOOD, N. (Ed.). Marketing in evolution: essays in honor of Michael J. Baker. London: Macmillan, 1996.

GRÖNROOS, C. Value-driven relational marketing: from products to resources e competencies. Journal of Marketing Management, v. 13, n. 5, p. 407-419, 1997.

HAIR, J. J. F et al. Análise multivariada de dados. 5 ed. Porto Alegre: Bookman, 2009.

HANKANSSON, H. International marketing and purchasing of industrial goods: an interaction approach. Ringwood: Pintail Studio Ltda. 1982. Disponível em:

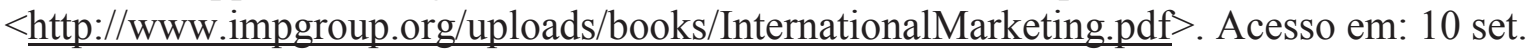
2009.

HANKANSSON, H.; SNEHOTA, I. Developing relationships in business network. London: Routledge. 1995. Disponível em: $<$ http://www.impgroup.org/uploads/books/0-41511570-1.pdf>. Acesso em: 10 set. 2009.

HONG, S.; WANG, Y. When relationship marketing collides with technology. Journal of Relationship Marketing, v. 8, n. 3, p. 218-230, 2009.

IACOBUCCI, Dawn; CHURCHILL JR., Gilbert A. Marketing research: methodological foundations (with Qualtrics Card). 10. ed. South-Western: Cengage Learning, 2009.

IBGE - Instituto Brasileiro de Geografia e Estatística. Disponível em:

$<$ http://www.ibge.gov.br/home/presidencia/noticias/noticia_impressao.php?id_noticia $=1273>$. Acesso em: 23 dez. 2009.

KALYANAM, K.; McINTYRE, S. The e-marketing mix: a contribution of the e-tailing wars. Journal of the Academy of Marketing Science, v. 30, n. 4, p. 487-499, 2002.

KOTLER, P. Administração de marketing: análise, planejamento, implementação e controle. São Paulo: Atlas, 2006.

LINDGREEN, A.; PALMER, R.; VANHAMME, J. Contemporary marketing practice: theoretical propositions and practical implications. Marketing Intelligence e Planning, v. 22, n. 6, p. 673-692, 2004.

MALHOTRA, N. Pesquisa de marketing: uma orientação aplicada. 4. ed. Porto Alegre: Bookman, 2006.

PELS, J.; BRODIE, R. J. Profiling marketing practice in an emerging economy: the Argentine case. Journal of Global Marketing, New York, v. 17, n. 1, p. 67-91, jan 2004.

PELS, J.; COVIELLO, N. E.; BRODIE, R. J. Integrating transactional and relational marketing exchange: a pluralistic perspective. Journal of Marketing Theory and Practice, v. 8, n. 3, p. 11-20, Summer 2000.

SHETH, J. N.; PARVATIYAR, A. Relationship marketing in consumer markets: antecedents and consequences. Journal of the Academy of Marketing Science, v. 23, n. 4, p. 255-71, 1995. 
VIEIRA, S. Análise de variância: ANOVA. São Paulo: Atlas, 1969.

WAGNER, Ralf. Contemporary marketing practices in Russia. European Journal of Marketing, Bradford, v. 39, n. 1-2, p. 199-215, 2005.

XAVIER R. O.; DORNELAS, J. S. O papel do gerente num contexto de mudança baseada no uso da tecnologia CRM. Revista de Administração Contemporânea, Rio de Janeiro, v. 10, n. 1, p. 9-30, jan./mar. 2006.

ZINELDIN, M.; PHILIPSON, S. Kotler and Borden are not dead: myth of relationship marketing and truth of 4Ps. Journal of Consumer Marketing, Reino Unido, v. 24, n. 4, p. 229-241, 2007. 